\title{
Precipitation Kinetics During Aging of an Alumina-Forming Austenitic Stainless Steel
}

\author{
Geneva Trotter ${ }^{\mathrm{a}}$, Bin $\mathrm{Hu}^{\mathrm{a}}$, Annie Y. Sun ${ }^{\mathrm{a}}$, Reed Harder ${ }^{\mathrm{a}}$, M.K. Miller ${ }^{\mathrm{b}}$, Lan Yao ${ }^{\mathrm{b}}$, Ian $_{\text {Baker }}^{\mathrm{a}}$ \\ ${ }^{\mathrm{a}}$ Thayer School of Engineering, Dartmouth College, Hanover, NH 03755 \\ ${ }^{\mathrm{b}}$ Center for Nanophase Materials Sciences, Oak Ridge National Laboratory, Oak Ridge, TN \\ 37831 \\ Corresponding author: Ian Baker, 14 Engineering Drive, Dartmouth College, Hanover, NH, \\ 03755, U.S.A.; telephone number: 1-603-646-2184; email: Ian.Baker@ dartmouth.edu
}

\begin{abstract}
The microstructural evolution of DAFA26, an alumina-forming austenitic (AFA) stainless steel, was investigated during aging. The effect of aging at $750^{\circ} \mathrm{C}$ and $800^{\circ} \mathrm{C}$ on the growth of spherical $\gamma^{\prime}-\mathrm{Ni}_{3}(\mathrm{Al}, \mathrm{Ti})$ particles present in the as-processed state was studied extensively using X-ray diffraction, microhardness testing, scanning electron microscopy, transmission electron microscopy, and atom probe tomography. The $\gamma^{\prime}$ particles had a cube-on-cube orientation relationship with the matrix (i.e. $\left.\left((010)_{\mathrm{m}} / /(010)_{\mathrm{p}},[100]_{\mathrm{m}} / /[100]_{\mathrm{p}}\right)\right)$. The coarsening kinetics of $\gamma^{\prime}-\mathrm{Ni}_{3} \mathrm{Al}$ particles were in agreement with the Lifshitz, Slyozof-Wagner theory. Coarse Laves phase particles were also present in the as-processed state, and during the aging process both smaller Laves phase precipitates and $\mathrm{B} 2-\mathrm{NiAl}$ precipitates formed on both the grain boundaries and in the matrix. The $\gamma^{\prime}$ precipitates were determined to have the most impact on the room temperature hardness.
\end{abstract}

Keywords: austenite; intermetallics; aging; coarsening; grain boundaries; precipitation 


\section{Introduction}

Currently there is an effort to develop new materials that will enable fossil fuel-burning power plants to operate more efficiently. In order to work in power plants that can operate in the ultra super critical (USC) range of $760^{\circ} \mathrm{C} / 35 \mathrm{MPa}$, the materials used for these systems must have excellent creep and corrosion resistance. Efficiency improvements as well as reduced $\mathrm{CO}_{2}$ emissions are benefits that can be realized with the higher operating temperatures obtained with advanced materials [1-4]. Alloyed with aluminum to provide corrosion resistance, aluminaforming austenitic (AFA) stainless steels have shown promise for application in the harsh environments seen in energy production where strong materials that are both oxidation and corrosion resistant are needed [5-16].

AFAs have a wide composition range and continued study of this system is needed to find the optimal combination of alloying elements that provide the best creep strength while maintaining good oxidation and corrosion resistance at minimal cost for future commercialization [16]. The $\mathrm{B} 2-\mathrm{NiAl}$ phase is commonly found in AFAs at temperatures below $900^{\circ} \mathrm{C}$ due to the $\mathrm{Al}$ and $\mathrm{Ni}$ additions needed for alumina-scale formation and promotion of a single-phase matrix [15]. $\mathrm{Nb}$ is added because it increases oxidation resistance by improving the stability of the alumina-scale. The amount of $\mathrm{Nb}$ needed for this beneficial effect promotes $\mathrm{Fe}_{2} \mathrm{Nb}$ phase formation $[6,8,13$, 15]. In the newer grades of AFAs, the austenitic matrix needed for creep strength can be obtained, and MC-base precipitates or $\gamma^{\prime}-\mathrm{Ni}_{3} \mathrm{Al}$ have been added for creep strength $[9,14,16]$. Optimization of these alloys is difficult because the effects that different alloying elements and precipitates have on the creep strength of these steels are complex and oftentimes not well understood.

Recently, there has been a shift in focus on the development of AFAs. AFAs have traditionally been strengthened by $\mathrm{MC}$ and/or $\mathrm{M}_{23} \mathrm{C}_{6}$ carbides [16], and creep resistance in an AFA was shown to improve with an increase in nanoscale MC precipitates [11, 14]. Earlier studies of AFAs have noted the presence of $\gamma^{\prime}$ precipitates [16, 17], and new studies of AFAs have shown that nano-scale $\gamma^{\prime}-\mathrm{Ni}_{3}(\mathrm{Al}, \mathrm{Ti})$ precipitates can be used to improve creep resistance [15]. The present study utilizes X-ray diffraction (XRD), scanning electron microscopy (SEM), TEM, and APT to investigate the microstructural evolution of precipitates during aging in an $\mathrm{Fe}-14 \mathrm{Cr}$ - 
32Ni-3Nb-0.15Si-(3-4)Al-(1-3)Ti-(0-0.3)Zr wt. \%. This alloy was named '32Z', where the '32Z' refers to 3Al-2Ti with $\mathrm{Zr}$ additions, and exhibited a longer creep-life than Fe-based Superalloy A286 when tested at $750^{\circ} \mathrm{C} / 100 \mathrm{MPa}$ [15]. This paper calls the alloy 'AFA26,' which is similar to the title designated by Yamamoto et al. in [18]. AFA26 with the additions of C or B has been studied previously by $\mathrm{Hu}$ et al. and is referred to as 'AFA29' [19].

\section{Experimental}

The AFA26 specimens were processed at Oak Ridge National Laboratory (ORNL). 600g ingots were arc-melted using pure element feedstock. The arc-melted ingots were then drop cast into a 1 " x 1" x 3" bar shaped die, soaked for $2 \mathrm{hrs}$ at $1100^{\circ} \mathrm{C}$ in $\mathrm{Ar}+4 \% \mathrm{H}_{2}$ gas, and then hot-rolled along the longitudinal axis with an approximately $15-20 \%$ thickness reduction per pass until the desired thickness reduction (up to 80\%) was achieved. The same homogenization temperature of $1100^{\circ} \mathrm{C}$ was then used to solutionize the plate for $30 \mathrm{~min}$. in $\mathrm{Ar}+4 \% \mathrm{H}_{2}$ gas, followed by aircooling. Table 1 includes both the nominal composition and analyzed composition of AFA26.

XRD analysis of the AFA26 was performed using a Rigaku D/Max 2000 diffractometer using Cu $\mathrm{K} \alpha$ radiation $(\lambda=0.1541 \mathrm{~nm})$. Specimens were cut from treated ingots and polished with successively finer grits of silicon carbide paper up to 1200-grit, followed polishing with 0.3 and $0.05 \mu \mathrm{m}$ alumina powder in water to obtain a mirror finish. XRD measurements were performed by scanning $2 \theta$ from $20^{\circ}$ to $140^{\circ}$ using a step size of 0.02 . MDI Jade software was used to identify phases in the alloys and to analyze the diffraction patterns. A tube voltage of $40 \mathrm{kV}$ and anode current of $300 \mathrm{~mA}$ was used.

Vickers microhardness data was used to provide insight into the alloy's aging characteristics. Specimens were mounted in phenolic resin and polished as described above to a mirror finish using $0.3 \mu \mathrm{m}$ alumina powder. Tests were performed at room temperature using a TIME TH713 Microhardness Tester under a load of 1.96 N (200 g) with a 15 s dwell time.

TEM, SEM, and APT analyses of the AFA26 were also performed. TEM specimens were prepared by cutting rectangular bars and milling them into $3 \mathrm{~mm}$ diameter cylinders. The cylinders were then cut into $3 \mathrm{~mm}$ discs, which were mechanically thinned and polished to 
$\sim 150 \mu \mathrm{m}$ thick and electropolished using a Struers TenuPol-5 twin-jet electropolisher at $11 \mathrm{~V}$ and $\sim 180 \mathrm{~mA}$ in a solution of $25 \%$ nitric acid in methanol at $-20^{\circ} \mathrm{C}$. The thin-foils were examined in an energy dispersive X-ray microanalysis (EDS)-equipped FEI Tecnai FS20ST field emission gun (FEG) TEM operated at $200 \mathrm{kV}$. The resulting thin foils were also examined in a FEI XL30 FEG SEM operated at $15 \mathrm{kV}$. APT analysis was performed at ORNL using a Cameca instruments local electrode atom probe (LEAP) 4000X HR. Specimens were annular milled in an FEI Nova 200 dual beam focused ion beam (FIB) equipped-SEM after being electropolished in a solution of $2 \%$ perchorlic acid and 98\% 2-butoxyethanol. Some specimens were fabricated by FIB annular milling and a lift-out procedure [20]. During voltage-mode APT experiments, a specimen temperature of $50 \mathrm{~K}$, a pulse fraction of $20 \%$, and a pulse repetition rate of $200 \mathrm{kHz}$ were used.

\section{Results and Discussion}

The as-processed AFA26 had a grain size of $20 \mu \mathrm{m}$ and showed a small amount of grain growth to $28 \mu \mathrm{m}$ after aging for $3000 \mathrm{~h}$. Figure 1 shows XRD patterns of the AFA26 in the as-hot-rolled state and after aging for $2,72,720$, and $3000 \mathrm{~h}$ at $750^{\circ} \mathrm{C}$. F.c.c., B2, $\gamma^{\prime}$, and Laves phase peaks are labeled. The f.c.c. and C14 Laves phase peaks are of similar intensities throughout the aging sequence, while the $\gamma^{\prime}$ and B2 peaks become more prominent as the aging time increases: the $\gamma^{\prime}$ (110) peak was only strong enough to be detected in the XRD pattern after the material had been aged for $3000 \mathrm{~h}$. Lattice constant evaluation was done using the Pawley method [21] through the Whole Pattern Fitting routine in the MDI Jade software. The Pawley method is an approach that was designed to address problems caused by overlapping peaks and uses whole pattern fitting to extract integrated intensities and refine the peak positions. The lattice constant is calculated based on the $\gamma^{\prime}$ phase $2 \theta$ angles, including the lowest angle (110) peak. Whole pattern fitting of the diffraction pattern yielded lattice parameters for the specimens annealed for $3000 \mathrm{~h}$. The lattice parameter of the f.c.c. matrix was calculated to be $\mathrm{a}=0.3602 \mathrm{~nm}$ and that for the $\gamma^{\prime}$ phase was a $=0.3595 \mathrm{~nm}$. Thus, the lattice misfit between the $\gamma$ ' precipitates and the f.c.c. matrix is $0.19 \%$. The lattice parameter of the $\mathrm{B} 2-\mathrm{NiAl}$ was a $=0.2892 \mathrm{~nm}$ and those for the $\mathrm{C} 14 \mathrm{Fe}_{2} \mathrm{Nb}$ Laves phase, $\mathrm{a}=0.4823 \mathrm{~nm}$ and $\mathrm{c}=0.7865 \mathrm{~nm}$. 
AFA29 is an AFA stainless steel that has a similar nominal composition to the AFA26, but also has an addition of $0.1 \mathrm{wt} . \% \mathrm{C}$ and $0.01 \mathrm{wt} \% \mathrm{~B}$. The lattice parameter estimates for the $\gamma$, f.c.c. matrix, and B2-NiAl in AFA26 are similar to the synchrotron XRD measured values for AFA29 after being aged for $240 \mathrm{~h}\left(\gamma^{\prime}, \mathrm{a}=0.3599 \mathrm{~nm}\right.$, f.c.c., $\left.\mathrm{a}=0.3609 \mathrm{~nm}, \mathrm{~B} 2-\mathrm{NiAl} \mathrm{a}=0.2892 \mathrm{~nm}\right)$ [19].

Backscattered electron (BSE) images of the microstructure of AFA26 in both the as-processed condition and after aging are shown in Figure 2. A number of microstructural changes can be observed. Twins were present in both the as-processed and aged AFA26. In comparison, no twins were observed in AFA29 [22]. This is not surprising since it has been shown that boron, which is present in AFA29, can lower the twin density in f.c.c. alloys [23, 24]. The Laves phase precipitates in the as-processed AFA26 (Figure 2a) are elongated along the rolling direction in a fashion similar to the Laves phase precipitation in a Fe-25\%Al-3\% Nb alloy that was forged at $1150^{\circ} \mathrm{C}$, which also had coarse and elongated Laves phase precipitates [25]. After aging for $2 \mathrm{~h}$ (Figure 2b) the material has additional grain boundary coverage consisting of alternating Laves and NiAl particles. This alternating grain boundary pattern was present in small amounts in the as-processed condition, and is often more easily observed in images of AFAs that have been exposed to prolonged aging at high temperature. The grain boundary coverage by precipitates increases as the material is aged from 72 to $3000 \mathrm{~h}$ (Figure 2c-e).

SEM-BSE images of AFA26 acquired at higher magnifications (Figure 3a-c) better illustrate the grain boundary precipitation trends. Figure $3 d$ is a secondary electron (SE) image that more clearly shows topographic contrast and the presence of the $\gamma^{\prime}$ precipitates. In the as-processed AFA26 (Figure 3a), there is very little grain boundary precipitation apart from large Laves phase precipitates. Figure $3 \mathrm{~b}$ shows discontinuous precipitation (or cellular growth) in the AFA26 aged for $2 \mathrm{~h}$. As the material is aged up to $720 \mathrm{~h}$ (Figure 3c) more grain boundary precipitation is evident and alternating $\mathrm{NiAl}$ and Laves phase precipitates are visible. This alternating precipitation is similar to what has been observed in previous studies on the evolution of precipitation in AFA-type alloys $[9,11,17,26]$. The grain boundary includes both the coarse Laves phase particles and the smaller alternating $\mathrm{NiAl}$ and Laves phase particles, these most likely occur because the $1100^{\circ} \mathrm{C}$ homogenization temperature used is within the temperature 
range that produces growth of the coarse Laves phase particles. The observation of coarse Laves phase particles being present at lower homogenization temperatures was noted previously in a similar alloy studied by Yamamoto et. al [15]. For example, Fe-20Cr-30Ni-2Nb-5Al (at. \%), which was homogenized at $1250^{\circ} \mathrm{C}[17,26,27]$ and AFA alloy " $41 \mathrm{Z}$ " studied by Yamamoto et al., which was homogenized at $1200^{\circ} \mathrm{C}$ [15], had no coarse Laves phase on the grain boundaries, since these heat treatments were above the Laves phase solvus temperature. As shown in Figure $3 \mathrm{c}-\mathrm{d}$ there are not only alternating Laves-NiAl particles on the grain boundaries, but B2-NiAl particles appear to have grown from the larger Laves phase particles that were present in the matrix before aging (Figure 2e and Figure 3d). In addition to notable changes in grain boundary precipitation, Figure 3c-d show the presence of $\gamma^{\prime}$ particles. The particles are visible in the SEM images after aging for $720 \mathrm{~h}$ (Figure 3c) and have grown noticeably in size after aging at $3000 \mathrm{~h}$ (Figure 3d). In Figure 3c-d, randomly distributed in the matrix are what appear to be small needle-shaped, Laves phase and B2-NiAl co-precipitates (indicated by yellow arrows).

The Laves phase particles present in the as-processed case grow as the alloy is aged. Figure 4 shows images of as-processed AFA26 (Figure 4a) and after $3000 \mathrm{~h}$ aging (Figure 4b). In the asprocessed case, the Laves phase particles are in bands along the rolling direction, but as the sample is aged, the particles spread out more uniformly. In Figure 4a, the volume fraction of Laves phase particles in the as-processed state is $3.6 \%$ and the average particle size is $1.8 \mu \mathrm{m}$, while in Figure $4 \mathrm{~b}$ the volume fraction of the Laves phase particles after aging at $3000 \mathrm{~h} \mathrm{is} 6.1 \%$ and the average particle size is $2.5 \mu \mathrm{m}$. After $3000 \mathrm{~h}$ of aging, precipitation of new Laves phase grain boundary precipitates increased the total overall volume fraction of the Laves phase by 2\%. Despite some initial precipitation before aging, additional Laves phase may have precipitated because the $\mathrm{Nb}$ is still supersaturated in the matrix. With aging over longer periods of time, more and more precipitates precipitate out either on the grain boundaries or contributed to the growth of Laves phase particles in the matrix. The volume fraction of the coarse Laves phase particles is similar to the $7.5 \%$ volume fraction determined from the aforementioned $\mathrm{Fe}$ $25 \% \mathrm{Al}-3 \% \mathrm{Nb}$ alloy, which had Laves phase precipitates with a width of $\sim 1 \mu \mathrm{m}$ and a length of several microns [25]. 
Bright field (BF) TEM images showed the morphology and size of the $\gamma^{\prime}-\mathrm{Ni}_{3}(\mathrm{Al}, \mathrm{Ti})$ precipitates present in aged AFA26. The $\gamma^{\prime}-\mathrm{Ni}_{3}(\mathrm{Al}, \mathrm{Ti})$ precipitates are spherical after aging for $72 \mathrm{~h}$ (Figure $5 a)$. Figure $5 b$ shows a selected area diffraction (SAD) pattern taken from the matrix [001] zone axis of this specimen in which two sets of diffraction spots are visible. The brighter spots arise from the f.c.c. matrix and $\gamma^{\prime}$ phase, and the weaker diffraction spots are $\gamma^{\prime}-\mathrm{Ni}_{3}(\mathrm{Al}, \mathrm{Ti})$ superlattice reflections. The $\gamma / \gamma^{\prime}$ microstructure observed in AFA26 is common in Ni-based superalloys [28]. Analogous to the analysis of AFA29 stainless steel [19] and other alloys that have been strengthened by $\gamma^{\prime}-\mathrm{Ni}_{3}(\mathrm{Al}, \mathrm{Ti})$ precipitates [15] the orientation relationship between the $\gamma^{\prime}$ phase and the f.c.c. matrix in AFA26 was determined to be cube-on-cube (i.e. $\left((010)_{\mathrm{m}} / /(010){ }_{\mathrm{p}}\right.$, $\left.\left.[100]_{\mathrm{m}} / /[100]_{\mathrm{p}}\right)\right)$. TEM-EDS results from $720 \mathrm{~h}$-annealed material show the composition of Laves and $\mathrm{NiAl}$ particles that formed on grain boundaries (Figure 6). The Laves phase grain boundary particles have high Fe (45.6 at. \%), Cr (10.5 at. \%), Ni (14.8 at. \%), and Nb content (18.1 at. \%) and the NiAl particles have high $\mathrm{Ni}(46.1$ at. \%), $\mathrm{Fe}$ (9.7 at. \%), and $\mathrm{Al}(38.9$ at. \%) content. The compositions are similar to those reported for $\mathrm{Al}$ and $\mathrm{Nb}$-rich precipitates in $\mathrm{Fe}$ $20 \mathrm{Cr}-30 \mathrm{Ni}-2 \mathrm{Nb}-5 \mathrm{Al}$ (at. \%) that was solutionized, cold-worked to 50\%, and aged for $240 \mathrm{~h}$ at $800^{\circ} \mathrm{C}$. For example, in the NiAl particle, while the Fe content is lower (9.7 versus 25.1 at. \%), the approximately $1: 1$ atomic ratio of $\mathrm{Ni}: \mathrm{Fe}$ and $\mathrm{Al}$ is maintained [17]. Figure 7 shows BF-TEM images of the $\gamma^{\prime}$ particles after aging for both $720 \mathrm{~h}$ and $3000 \mathrm{~h}$ at $750^{\circ} \mathrm{C}$. Compared to the material aged for $720 \mathrm{~h}$ at $750^{\circ} \mathrm{C}$ (Figure 7a), the $\gamma^{\prime}$ precipitates after aging for $3000 \mathrm{~h}$ (Figure 7b) are noticeably larger (52 and $90 \mathrm{~nm}$, respectively). Even after long-term aging the $\gamma^{\prime}-$ precipitates remain spherical. Creep testing of this alloy at $750^{\circ} \mathrm{C}$ appears to have little impact on the size evolution of $\gamma^{\prime}$ precipitates. The $\gamma^{\prime}$ precipitate size values are similar to what has been previously reported [15] for AFA26 after $952 \mathrm{~h}$ creep testing $(71 \mathrm{~nm})$ at $750^{\circ} \mathrm{C}$ and in the AFA29 alloy (AFA26 with additions of C and B) after 3,008 h of testing (95 nm). The spherical particles observed in AFA26 is consistent with the calculated $0.19 \%$ misfit value. The morphology of $\gamma^{\prime}$ particles tends to be a function of the matrix-precipitate misfit. It has been observed that when $\gamma^{\prime}$ particles have a low misfit (less than $0.5 \%$ ) they tend to be spherical while at higher misfits they tend to be cuboidal [29]. In an AFA29 sampled annealed for $240 \mathrm{~h}$ after a thermomechanical treatment, spherical $\gamma^{\prime}$ particles were present with a $0.28 \% \gamma / \gamma^{\prime}$ misfit [19]. 
In addition to TEM analysis, APT observation of the AFA26 (Figure 8) was used to provide further insights into the nature of the $\gamma^{\prime}$ precipitates. Figure 8a shows a three-dimensional (3D) reconstruction of the as-processed AFA26 alloy with $\gamma^{\prime}$ particles visible. Only Al (green) and Ni (red) atoms are displayed, enabling the 3D identification of the $\gamma^{\prime}$ precipitates. The $\gamma^{\prime}$ precipitates were uniformly and randomly distributed throughout the AFA26 matrix. After AFA26 was aged at $750^{\circ} \mathrm{C}$ for $2 \mathrm{~h}$ (Figure $8 \mathrm{~b}$ ) the $\gamma^{\prime}$ particles showed growth to $6 \mathrm{~nm}$ as compared to their $4 \mathrm{~nm}$ size in the as-processed state.

Figure 9 shows proximity histograms across the $\gamma$-f.c.c. and $\gamma^{\prime}$ phases, revealing elemental partitioning between the phases. In the histogram for the as-processed AFA26 (Figure 9a), Ni (66 at. \%), $\mathrm{Al}(14$ at. \%), and $\mathrm{Ti}(10$ at. \%) are the major elements present in the $\gamma$ ' phase. Though the addition of $\mathrm{Ti}$ tends to lower the oxidation resistance of AFAs, $\mathrm{Ti}$ is thought to stabilize the $\gamma^{\prime}$ phase [15] and altering the Ti:Al ratio in superalloys has been shown to impact strength [30]. Much like in an Fe-25\%Al-3\% Nb alloy [25], only $\sim 1 \% \mathrm{Nb}$ was detected in the matrix. In Figure 9, the proximity histograms reveal that after $2 \mathrm{~h}$ of aging, $\mathrm{Al}$ (14 at. \%) showed little change in composition from the as-processed condition and the Ti content shows only a slight decrease from 10 at. $\%$ in the as-processed condition to 8 at. $\%$ after aging for $2 \mathrm{~h}$. The $\mathrm{Ni}$ content of the $\gamma^{\prime}$ phase is between 66 at. $\%$ and 71 at. $\%$ as the sample is aged up to $720 \mathrm{~h}$. After aging up to 72 and $720 \mathrm{~h}$ (Figure 9c and d, respectively) it appears that the particle composition is relatively stable with a slight decrease noted in $\mathrm{Fe}(9.3$ at. \% to 7.9 at. \%) and $\mathrm{Ni}(69.4$ at.\% to 66.7 at. \%).

$\gamma^{\prime}$ coarsening has been studied in a number of Fe- and Ni-based alloys [31-38], where particle coarsening rates for $\gamma$ ' follow the equations based on the Lifshitz, Slyozov [39] and Wagner [40] (LSW) theory. The LSW theory assumes a zero volume fraction [41], misfit-free spherical particles, and one-rate controlling solute [33]. According to LSW theory for volume diffusioncontrolled growth processes, particles follow the growth law:

$$
\overline{\mathrm{r}}^{3}-\overline{\mathrm{r}}_{0}{ }^{3}=\mathrm{kt}
$$


where $\overline{\mathrm{r}}$ and $\overline{\mathrm{r}}_{0}$ correspond to the average particle radius at time $t$ and at the onset of coarsening, respectively, and $\mathrm{k}$ is the coarsening rate constant given by:

$$
\mathrm{k}=\frac{8 \gamma \mathrm{DV}_{\mathrm{m}} \mathrm{C}_{\mathrm{e}}}{9 \mathrm{RT}}
$$

where $\gamma$ is the particle/matrix interfacial energy $\left(\mathrm{J} / \mathrm{m}^{2}\right), \mathrm{D}$ is the diffusion coefficient of solute in the matrix $\left(\mathrm{m}^{2} / \mathrm{s}\right), \mathrm{V}_{\mathrm{m}}$ is the precipitate molar volume $\left(\mathrm{m}^{3} / \mathrm{mol}\right), \mathrm{C}_{\mathrm{e}}$ is the equilibrium concentration of solute in the matrix, $\mathrm{R}$ is the universal gas constant $(\mathrm{J} / \mathrm{mol}-\mathrm{K})$, and $\mathrm{T}(\mathrm{K})$ is the aging temperature.

AFA26 was also aged at $800^{\circ} \mathrm{C}$ and the coarsening behavior of $\gamma^{\prime}$ particles was observed via SEM (Figure 10). Similar to aging at $750^{\circ} \mathrm{C}, \gamma^{\prime}$ precipitates aged at $800^{\circ} \mathrm{C}$ had a spherical morphology at the early stages of aging and remained spherical as the particles continued to grow for $240 \mathrm{~h}$. The diameters of the $\gamma^{\prime}$ particles at 2.4, 24, and $240 \mathrm{~h}$ were 18, 28, and $62 \mathrm{~nm}$, respectively.

The evolution of the size of the $\gamma^{\prime}$ particles both at 750 and $800^{\circ} \mathrm{C}$ is shown in a plot of $\bar{r}^{3}-\bar{r}_{0}^{3}$ versus t (Figure 11). A linear relationship between the particle size and the cube-root of time was determined for both temperatures that satisfies the predictions of LSW theory. As expected, the $\gamma^{\prime}$ particles show a faster coarsening at $800^{\circ} \mathrm{C}$ as compared to $750^{\circ} \mathrm{C}$ : the coarsening rate constant was determined from the slope $\left(\mathrm{k}=0.0085 \mathrm{~nm}^{3} / \mathrm{s}\right.$ at $750^{\circ} \mathrm{C}$ and $\mathrm{k}=0.0344 \mathrm{~nm}^{3} / \mathrm{s}$ at $\left.800^{\circ} \mathrm{C}\right)$.

In addition to $\gamma^{\prime}$ particle composition, trends in the evolution of the matrix composition were also revealed by APT. For example, based on APT data, as the material is aged up to $720 \mathrm{~h}$ the amount of $\mathrm{Fe}$ in the matrix increased from $\sim 42$ at. $\%$ to $\sim 56$ at. $\%$, while decreases were observed for $\mathrm{Ni}(\sim 33$ to 20 at. \%,), $\mathrm{Al}(\sim 7$ to 3 at. \%), and $\mathrm{Ti}(\sim 3$ to 0.4 at. \%). The decrease in Ni, $\mathrm{Al}$, and Ti can be explained by the growth of the $\gamma^{\prime}$ precipitates as well as the growth of NiAl particles on the grain boundaries. Keeping in mind that the analyzed amount of $\mathrm{Cr}$ in the as-processed 
AFA26 is 14.8 at. \%, the increase in $\mathrm{Cr}$ to 19 at. \% after $720 \mathrm{~h}$ would be expected because $\mathrm{Cr}$ is a minor component of all the precipitate phases found in the matrix.

Hardness measurements of AFA26 were performed on specimens aged at $750^{\circ} \mathrm{C}$ for 0,1 , 2, 8, 24, 72, 168, 720, and 3000 hours, and are summarized in Figure 12. The as-processed alloy showed a hardness of $294 \pm 20 \mathrm{HV}$. As the AFA26 is aged its hardness initially increased reaching a peak hardness of $486 \pm 39 \mathrm{HV}$ after $24 \mathrm{~h}$ of aging. After the hardness peaks, the alloy hardness decreases steadily to $387 \pm 11 \mathrm{HV}$ after $3000 \mathrm{~h}$.

Based on the analysis of the precipitate and matrix evolution, it is unlikely that the presence of the Laves phase has much impact on the room-temperature strength of AFA26. The increase in hardness that is observed up to $24 \mathrm{~h}(\sim 484 \mathrm{HV})$ and the subsequent decrease to $\sim 387 \mathrm{HV}$ after aging at $750^{\circ} \mathrm{C}$ for $3000 \mathrm{~h}$ is a result of $\gamma^{\prime}$ phase coarsening.

\section{Summary}

1. The microstructure of as-processed AFA26 is austenitic and consists of C14 $\mathrm{Fe}_{2} \mathrm{Nb}$ Laves phase and $\gamma^{\prime}-\mathrm{Ni}_{3}(\mathrm{Al}, \mathrm{Ti})$ particles. B2-NiAl particles form when the material is aged.

2. Laves phase particles aligned along the rolling direction were present both in the matrix and on the grain boundaries in the as-processed state. These particles showed little coarsening of their $\sim 2 \mu \mathrm{m}$ diameter during anneals at $750^{\circ} \mathrm{C}$ for up to $3000 \mathrm{~h}$. During aging, additional Laves phase particles nucleate and grow on the grain boundaries. These alternate with NiAl particles, which also precipitate on the grain boundaries. In addition, there is growth of $\mathrm{NiAl}$ on the Laves particles that were initially present in the asprocessed case.

3. APT and TEM analysis provided compositional data that showed that the matrix was depleted of $\mathrm{Ni}, \mathrm{Al}$, and $\mathrm{Ti}$ due to the growth of $\mathrm{Ni}_{3}(\mathrm{Al}, \mathrm{Ti})$ precipitates. Despite long-term aging up to $3000 \mathrm{~h}$, the $\mathrm{Ni}_{3}(\mathrm{Al}, \mathrm{Ti})$ particles remain spherical. The $\gamma^{\prime}$ precipitates have a cube-on-cube orientation relationship with the matrix (i.e. $\left((010)_{\mathrm{m}} / /(010)_{\mathrm{p}},[100]_{\mathrm{m}} / /\right.$ $\left.[100]_{\mathrm{p}}\right)$. 
4. The kinetics of $\mathrm{Ni}_{3}(\mathrm{Al}, \mathrm{Ti})$ precipitation show good agreement with the LSW theory, with a particle diameter length scale showing $\mathrm{t}^{1 / 3}$ growth.

5. The change in hardness with aging time is controlled by the size and volume fraction of the $\gamma^{\prime}-\mathrm{Ni}_{3}(\mathrm{Al}, \mathrm{Ti})$ precipitates.

\section{Acknowledgments}

This research was supported by National Science Foundation (NSF) Grant DMR 1206240 (GT) and the U.S. Department of Energy (DOE) under NETL Award DEFG2612FE0008857 (BH). Any opinions, findings, and conclusions or recommendations expressed in this material are those of the author(s) and do not necessarily reflect the views of the NSF or DOE. Atom probe tomography experiments were conducted at ORNL's Center for Nanophase Materials Sciences, which is a U.S. Department of Energy, Office of Science User Facility. The authors would like to acknowledge Dr. Yukinori Yamamoto and Dr. Michael P. Brady of ORNL for both providing the AFA stainless steels and for insightful advice. 


\section{References}

[1] R. Viswanathan, A.F. Armor, G. Booras, Power, 148 (2004) 42-49.

[2] R. Viswanathan, K. Coleman, U. Rao, International Journal of Pressure Vessels and Piping, 83 (2006) 778-783.

[3] V. Viswanathan, R. Purgert, P. Rawls, Advanced Materials and Processes, 8 (2008) 47-49.

[4] R. Viswanathan, J. Henry, J. Tanzosh, G. Stanko, J. Shingledecker, B. Vitalis, R. Purgert, Journal of materials engineering and performance, 14 (2005) 281-292.

[5] M.P. Brady, Y. Yamamoto, M.L. Santella, P.J. Maziasz, B.A. Pint, C.T. Liu, Z.P. Lu, H. Bei, JOM, 60 (July 2008) 12-18.

[6] Y. Yamamoto, M.P. Brady, Z.P. Lu, P.J. Maziasz, C.T. Liu, B.A. Pint, K.L. More, H.M. Meyer, E.A. Payzant, Science, 316 (2007) 433-436.

[7] Y. Yamamoto, M.P. Brady, Z.P. Lu, C.T. Liu, M. Takeyama, P.J. Maziasz, B.A. Pint, Metallurgical and Materials Transactions A, 38 (2007) 2737-2746.

[8] M.P. Brady, Y. Yamamoto, M.L. Santella, B.A. Pint, Scripta Materialia, 57 (2007) 1117-1120.

[9] Y. Yamamoto, M. Takeyama, Z.P. Lu, C.T. Liu, N.D. Evans, P.J. Maziasz, M.P. Brady, Intermetallics, 16 (2008) 453-462.

[10] M.P. Brady, Y. Yamamoto, B.A. Pint, M.L. Santella, P.J. Maziasz, L.R. Walker, Materials Science Forum, 595 (2008) 725-732.

[11] Y. Yamamoto, M.L. Santella, M.P. Brady, H. Bei, P.J. Maziasz, Metallurgical and Materials Transactions A, 40 (2009) 1868-1880.

[12] H. Bei, Y. Yamamoto, M.P. Brady, M.L. Santella, Materials Science and Engineering: A, 527 (2009) 2079-2086.

[13] M.P. Brady, Y. Yamamoto, M.L. Santella, L.R. Walker, Oxidation of Metals, 72 (2009) 311-333.

[14] Y. Yamamoto, M.P. Brady, M.L. Santella, H. Bei, P.J. Maziasz, B.A. Pint, Metallurgical and Materials Transactions A, 42 (2011) 922-931.

[15] Y. Yamamoto, G. Muralidharan, M.P. Brady, Scripta Materialia, 69 (2013) 816-819.

[16] M.P. Brady, J. Magee, Y. Yamamoto, D. Helmick, L. Wang, Materials Science and Engineering: A, 590 (2014) 101-115.

[17] G. Trotter, G. Rayner, I. Baker, P.R. Munroe, Intermetallics, 53 (2014) 120-128.

[18] Y. Yamamoto, G. Muralidharan, M.P. Brady, US Patent No. 8,815,146 (2014).

[19] B. Hu, G. Trotter, I. Baker, M.K. Miller, L. Yao, S. Chen, Z. Cai, Metallurgical and Materials Transactions A, 46 (2015) 3773-3785.

[20] M. Miller, K. Russell, G. Thompson, Ultramicroscopy, 102 (2005) 287-298.

[21] G. Pawley, Journal of Applied Crystallography, 14 (1981) 357-361.

[22] B. Hu, in: Thayer School of Engineering, Dartmouth College, Hanover, 2015, pp. 73-106.

[23] B. Rath, M. Imam, C. Pande, Mater. Phys. Mech, 1 (2000) 61-66.

[24] S. Mahajan, C.S. Pande, M.A. Imam, B.B. Rath, Acta Materialia, 45 (1997) 2633-2638.

[25] D.G. Morris, M.A. Muñoz-Morris, Intermetallics, 23 (2012) 169-176.

[26] G. Trotter, I. Baker, Materials Science and Engineering: A, 627 (2015) 270-276.

[27] G. Trotter, I. Baker, Philosophical Magazine, (2015) 1-17.

[28] R.C. Reed, The superalloys: fundamentals and applications, Cambridge university press, 2006.

[29] B.A. K, C.P. Sharma, Mechanical Behaviour and Testing of Materials, PHI Learning Private Limited, 2011.

[30] J. Jones, D. MacKay, SUPERALLOYS 1996, (1996) 417-424.

[31] K. Ducki, Journal of Achievements in Materials and Manufacturing Engineering, 18 (2006).

[32] Z. Zhong, Y. Gu, Y. Yuan, Materials Science and Engineering: A, 622 (2015) 101-107. 
[33] C. Schmuck, P. Caron, A. Hauet, D. Blavette, Philosophical Magazine A, 76 (1997) 527-542.

[34] H.T. Kim, S.S. Chun, X.X. Yao, Y. Fang, J. Choi, Journal of Materials Science, 32 (1997) 4917-4923.

[35] R.A. MacKay, M.V. Nathal, Acta Metallurgica et Materialia, 38 (1990) 993-1005.

[36] A. Baldan, Journal of Materials Science, 37 (2002) 2379-2405.

[37] A.M. Ges, O. Fornaro, H.A. Palacio, Materials Science and Engineering: A, 458 (2007) 96-100.

[38] S. Zhao, X. Xie, G.D. Smith, S.J. Patel, Materials Letters, 58 (2004) 1784-1787.

[39] I.M. Lifshitz, V.V. Slyozov, Journal of Physics and Chemistry of Solids, 19 (1961) 35-50.

[40] C. Wagner, Zeitschrift für Elektrochemie, Berichte der Bunsengesellschaft für physikalische Chemie, 65 (1961) 581-591.

[41] J.R. Groza, J.F. Shackelford, Materials Processing Handbook, CRC Press, 2007. 


\section{Figure Captions}

Figure 1. XRD patterns of bulk AFA26 specimens with visible peaks labeled ' $\gamma$ ' for the $\mathrm{L} 1_{2}$ particles, 'B2' for NiA1, and ' $\varepsilon$ ' for the Laves phase in the as-cast state and after aging at $2,72,720$, and $3000 \mathrm{~h}$.

Figure 2. BSE SEM images of AFA26 specimens: (a) as-processed, and aged at $750^{\circ} \mathrm{C}$ for (b) $2 \mathrm{~h}$; (c) $72 \mathrm{~h}$; (d) $720 \mathrm{~h}$; and (e) $3000 \mathrm{~h}$.

Figure 3. SEM images of AFA26 specimen grain boundaries: (a) as-processed, and aged at $750^{\circ} \mathrm{C}$ for (b) $2 \mathrm{~h}$; (c) $720 \mathrm{~h}$ and (d) $3000 \mathrm{~h}$.

Figure 4. SEM images of AFA26: (a) as-processed and (b) aged at $750^{\circ} \mathrm{C}$ for $3000 \mathrm{~h}$.

Figure 5. AFA26 aged for $72 \mathrm{~h}$ at $750^{\circ} \mathrm{C}$. (a) BF- TEM image; (b) SAD pattern from the [001] $\gamma$-matrix zone axis showing weak superlattice reflections (in yellow) from $\mathrm{L}_{2}-\gamma$ ' precipitates.

Figure 6. BF- TEM image (a), showing precipitation in a AFA26 specimen aged for $720 \mathrm{~h}$ at $750^{\circ} \mathrm{C}$, and EDS spectra from two different regions: (b) a Laves phase $\mathrm{Fe}_{2} \mathrm{Nb}$ precipitate and (c) a NiAl precipitate.

Figure 7. BF- TEM image of AFA 26 aged at $750^{\circ} \mathrm{C}$ for (a) $720 \mathrm{~h}$ and (b) $3000 \mathrm{~h}$ showing $\mathrm{L} 1_{2}$ precipitate growth.

Figure 8. An APT reconstruction of the AFA26 specimen with the $\mathrm{L}_{2}-\gamma$ ' particles bound by red isoconcentration surfaces: (a) as-processed alloy with a 45 at. $\% \mathrm{Ni}$ isoconcentration surface and (b) aged at $750^{\circ} \mathrm{C}$ for $2 \mathrm{~h}$ with a 55 at. $\% \mathrm{Ni}$ isoconcentration surface. The green points indicate the $\mathrm{Fe}$ in the f.c.c. matrix.

Figure 9. Proximity histograms across the $\gamma$-f.c.c. matrix and a $\gamma^{\prime}-\mathrm{L1}_{2}$ phase particle interfaces in AFA26: (a) as-processed; and aged at $750^{\circ} \mathrm{C}$ for (b) $2 \mathrm{~h}$, (c) $72 \mathrm{~h}$ and (d) $720 \mathrm{~h}$. The iron and nickel-rich f.c.c. matrix is on the left hand side and the $\gamma^{\prime}-\mathrm{L1}_{2}$ phase particle is on the right hand side.

Figure 10. SE SEM images of the $\mathrm{L} 1_{2}$ particles in AFA26 specimens aged at $800^{\circ} \mathrm{C}$ for: (a) 2.4 h; (b) $24 \mathrm{~h}$ and (c) $240 \mathrm{~h}$.

Figure 11. Plot of $\overline{\mathrm{r}}^{3}-\overline{\mathrm{r}}_{0}{ }^{3}$ versus aging for $\gamma^{\prime}$ particles in AFA26 aged at 750 and $800^{\circ} \mathrm{C}$. 
Figure 12. Hardness values for AFA26 aged at $750^{\circ} \mathrm{C}$ with error bars indicating measurement standard deviation. 10 indents were made for each aging time.

Table 1. AFA26 alloy composition (nominal and analyzed) 


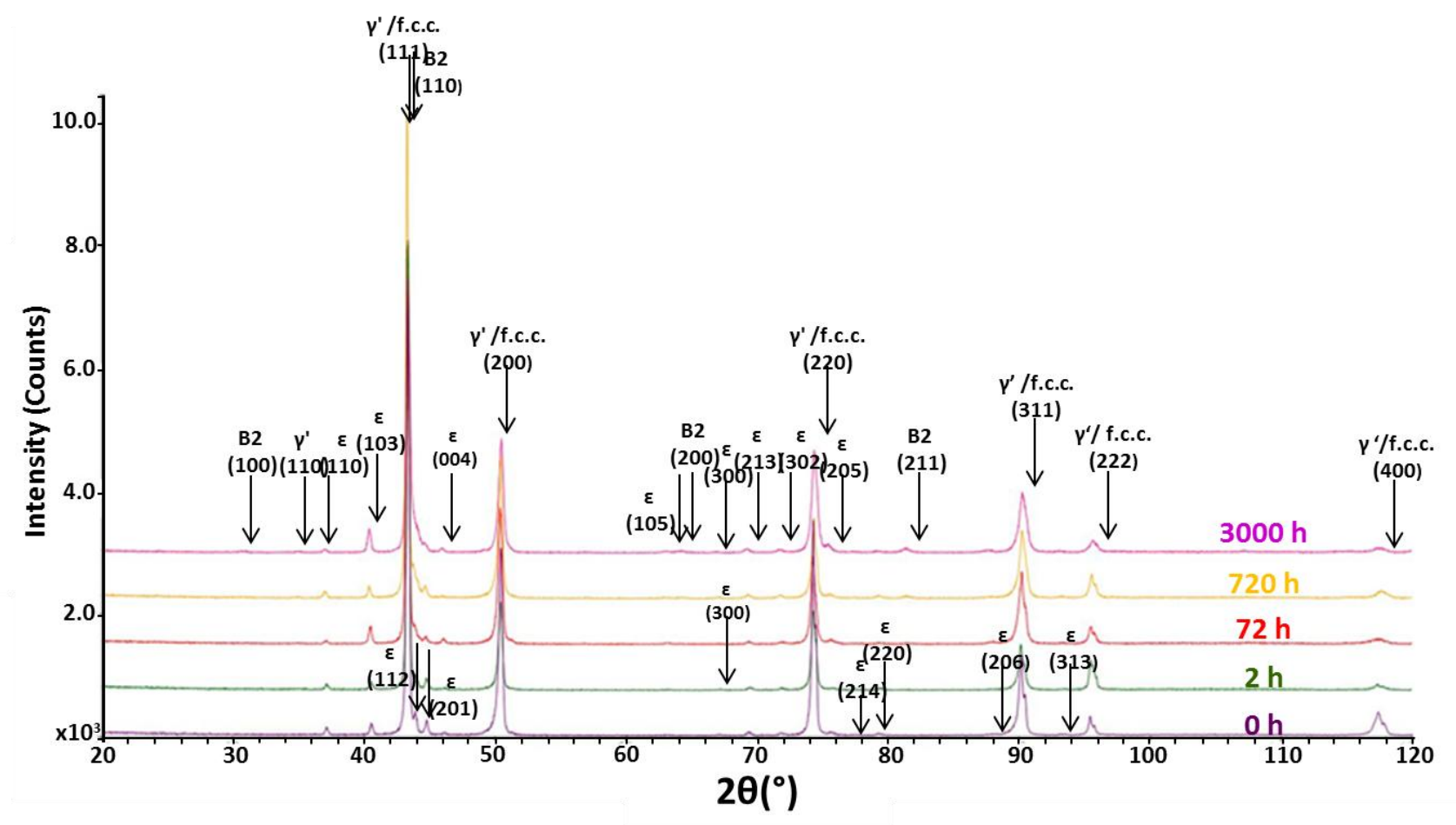

Figure 1. XRD patterns of AFA26 specimens in the as-cast state and after aging at 2, 72, 720, and $3000 \mathrm{~h}$ the peaks are labeled ' $\gamma$ ' for the $\mathrm{L} 1_{2}$ particles, 'B2' for the NiAl f.c.c. for the matrix, and ' $\varepsilon$ ' for the Laves phase. 


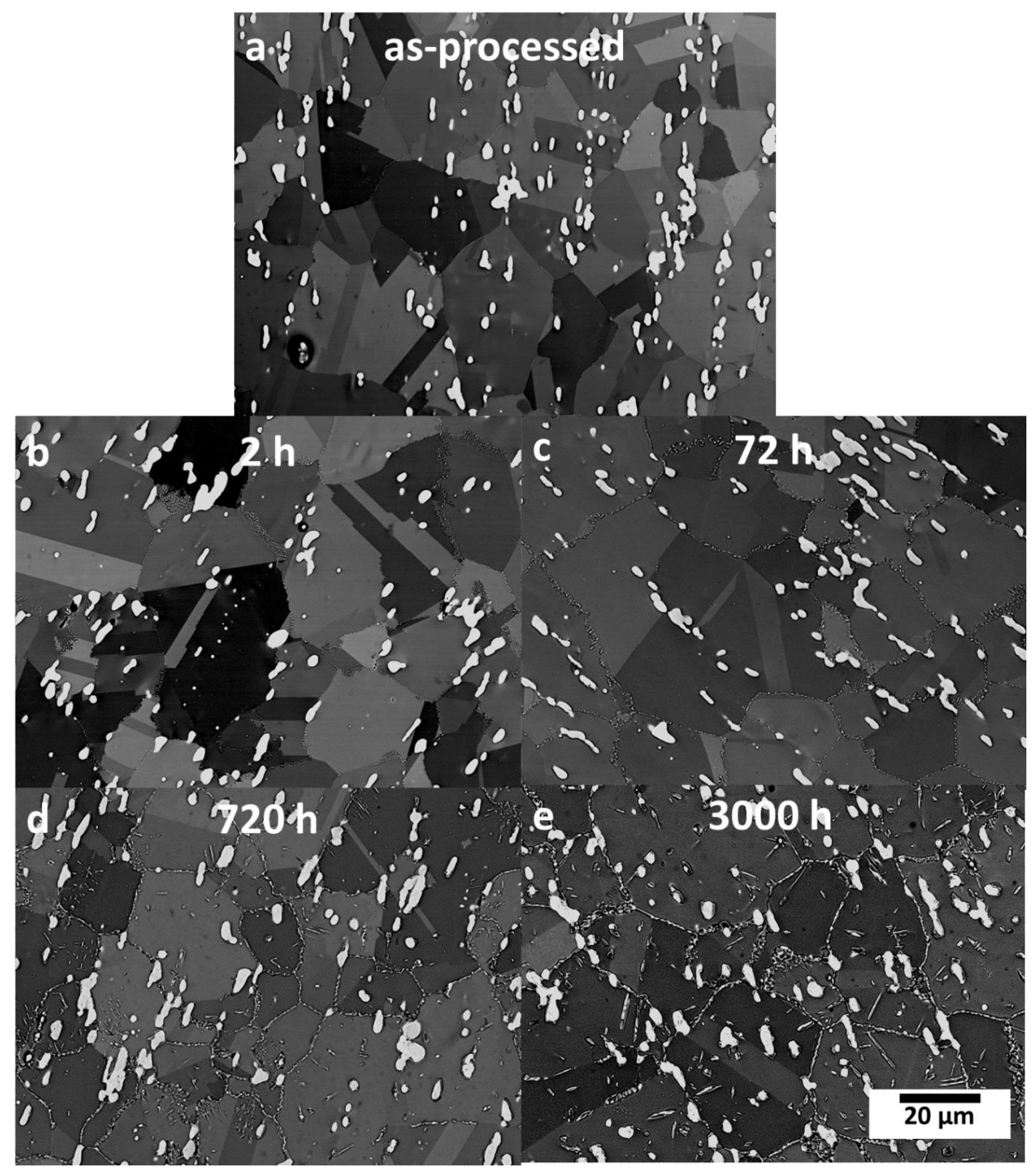

Figure 2. BSE images of AFA26 specimens: (a) as-processed, and aged at $750^{\circ} \mathrm{C}$ for (b) $2 \mathrm{~h}$;

(c) 72 h; (d) 720 h; and (e) 3000 h. The large white Laves phase precipitates are elongated and aligned along the rolling direction. 


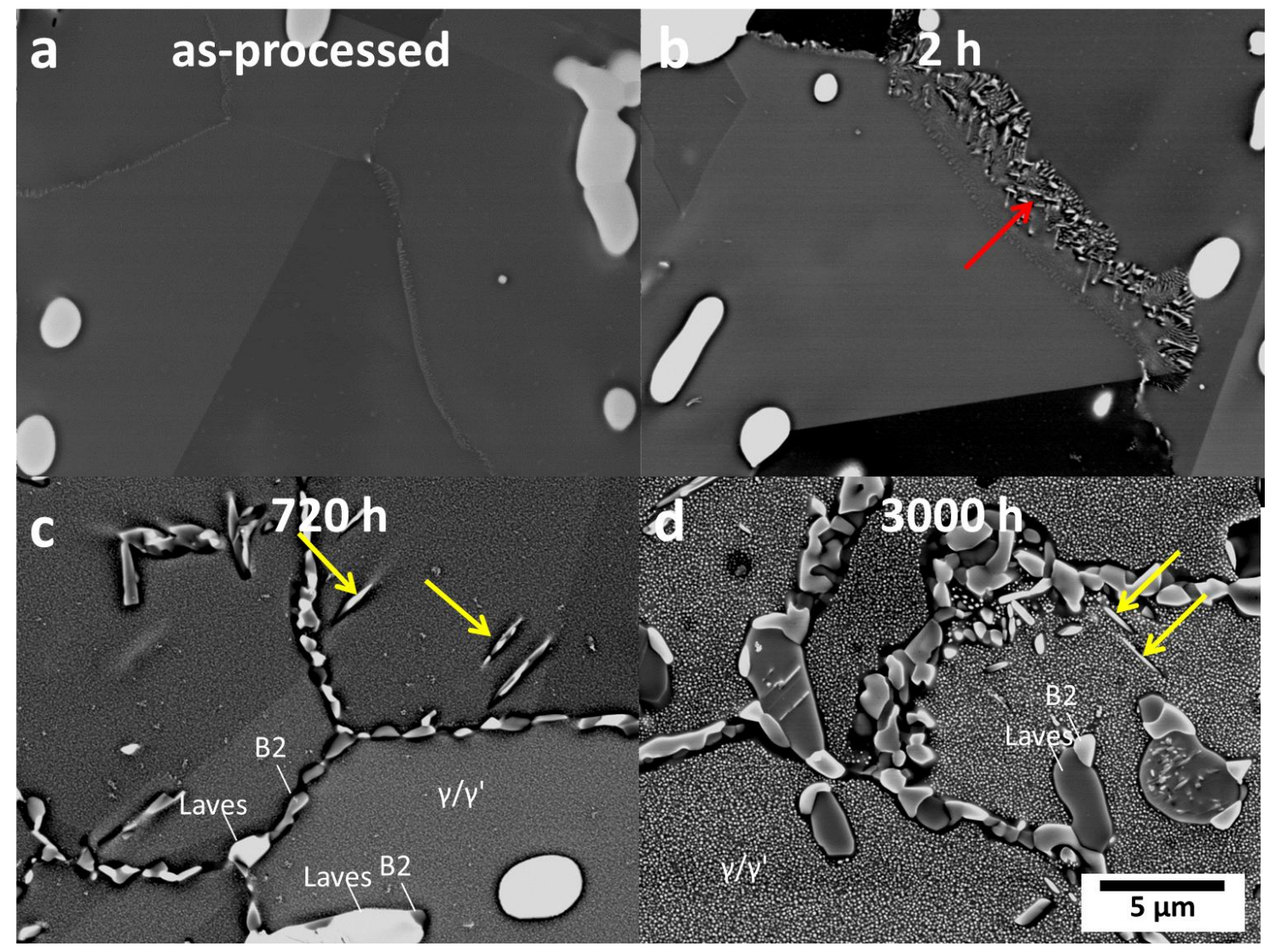

Figure 3. BSE images of AFA26 showing grain boundaries in specimens: (a) as-processed, and aged at $750^{\circ} \mathrm{C}$ for (b) $2 \mathrm{~h}$; (c) $720 \mathrm{~h}$ and (d) $3000 \mathrm{~h}$. The red arrow in (a) indicates cellular precipitation. Yellow arrows in (c) and (d) indicate the needle shape co-precipitates of Laves phase and B2-NiAl phase. 


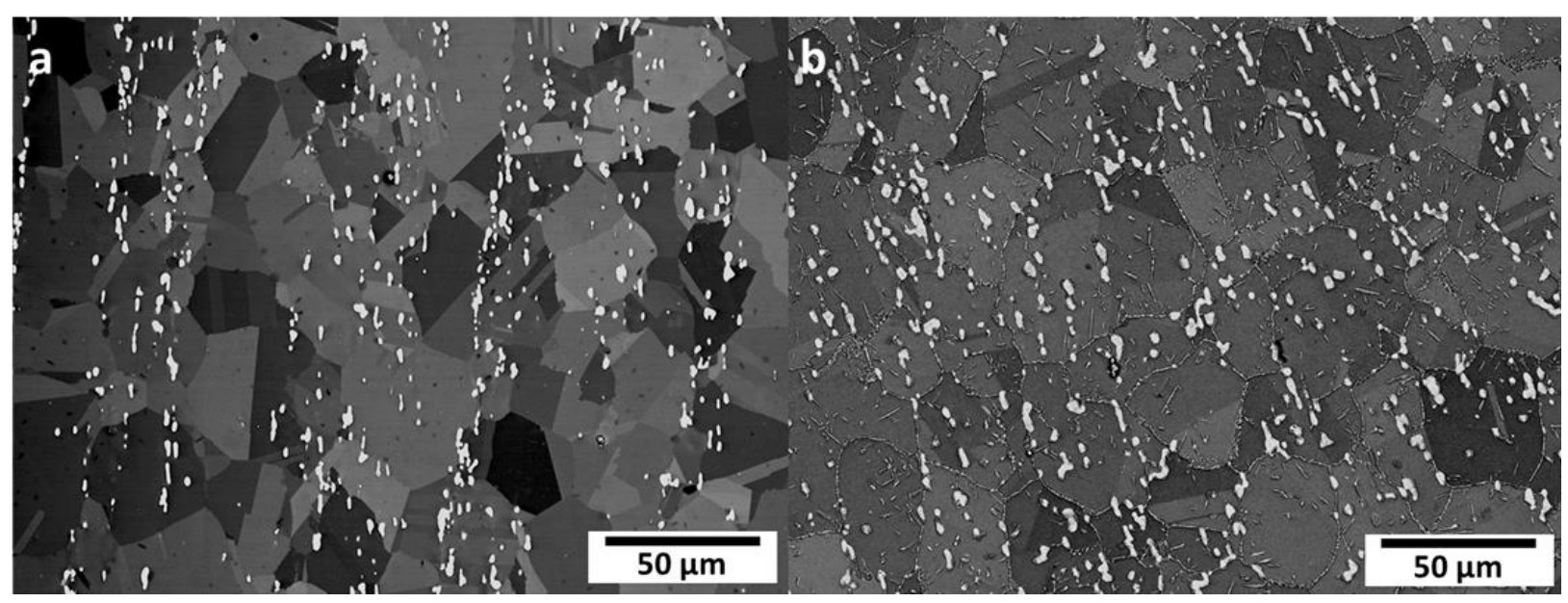

Figure 4. BSE images of AFA26: (a) as-processed and (b) aged at $750^{\circ} \mathrm{C}$ for $3000 \mathrm{~h}$. 


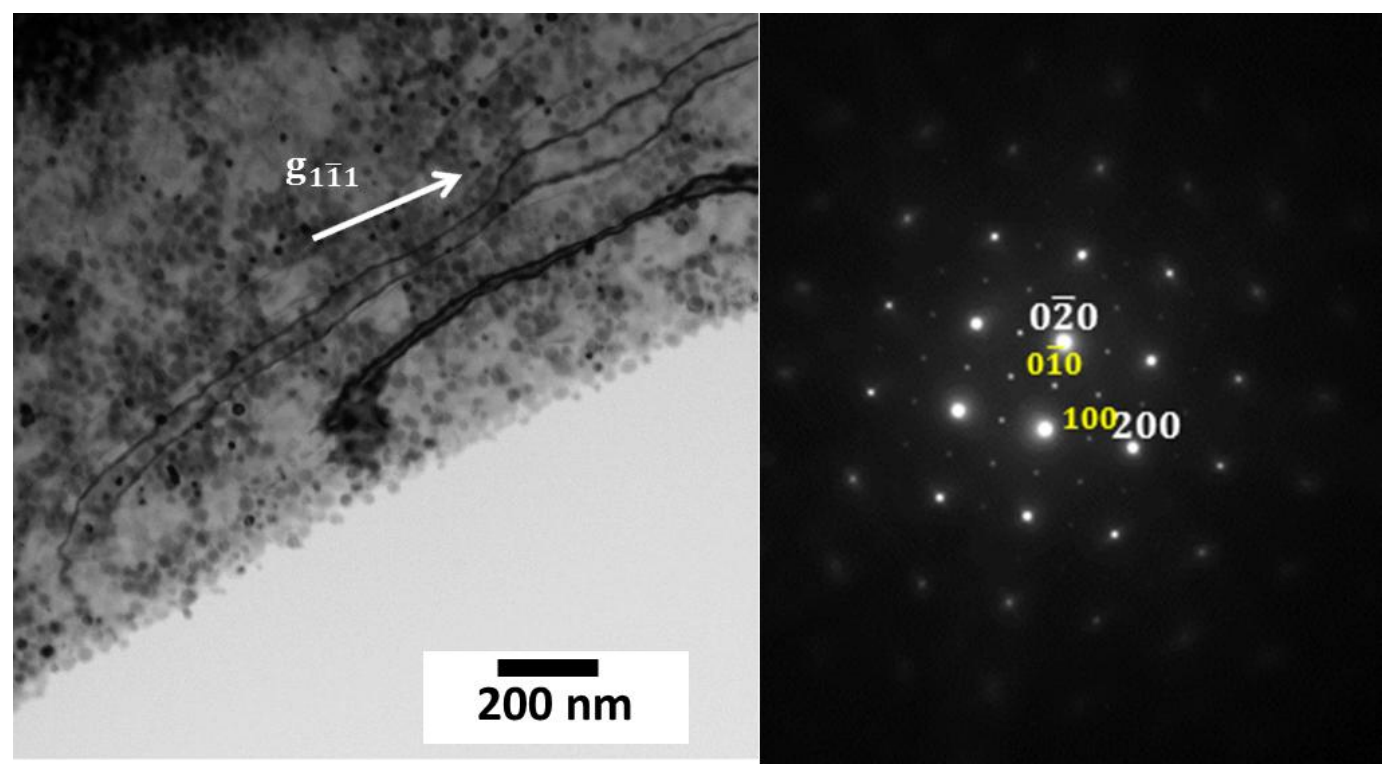

Figure 5. AFA26 aged for $72 \mathrm{~h}$ at $750^{\circ} \mathrm{C}$. (a) BF TEM image; (b) SAD from the [001] $\gamma$-matrix zone axis showing weak superlattice reflections (in yellow) from $\mathrm{L1}_{2}-\gamma^{\prime}$ precipitates. 


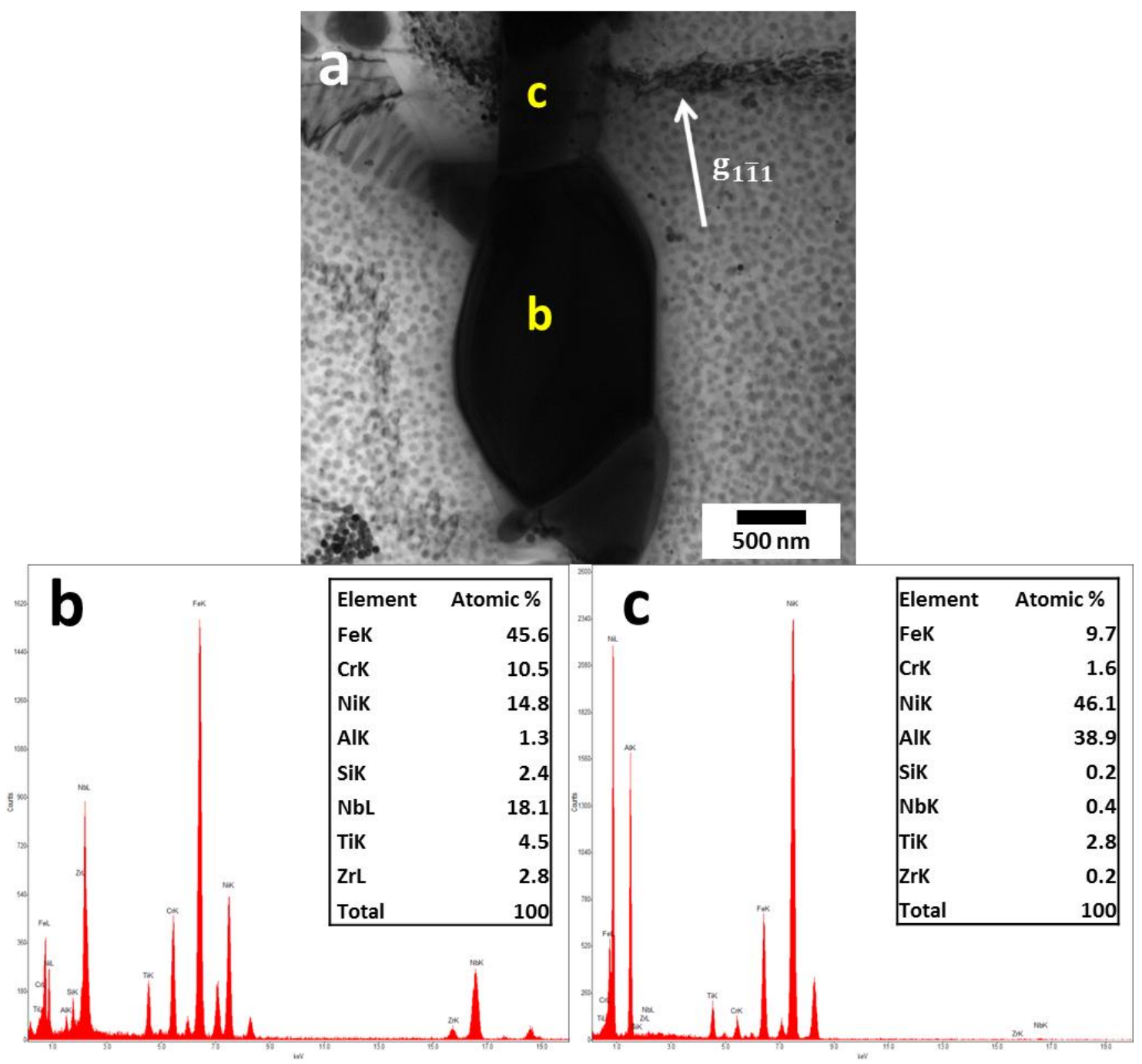

Figure 6. (a) BF TEM image showing precipitation in AFA26 aged for $720 \mathrm{~h}$ at $750^{\circ} \mathrm{C}$, and EDS spectra from two different regions: (b) a Laves phase $\mathrm{Fe}_{2} \mathrm{Nb}$ precipitate and (c) a $\mathrm{NiAl}$ precipitate. 


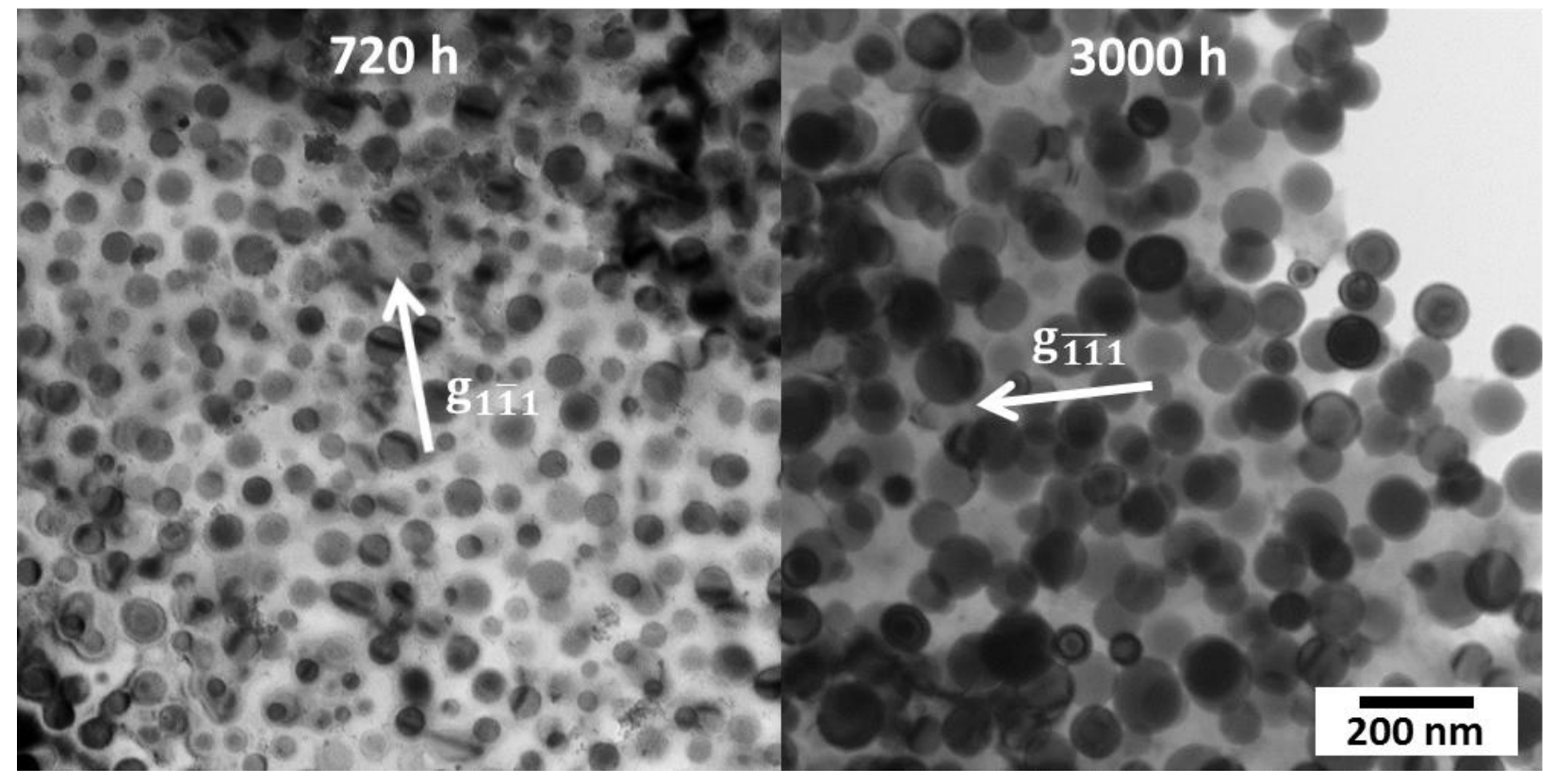

Figure 7. A bright-field TEM image of AFA26 aged at $750^{\circ} \mathrm{C}$ for (a) $720 \mathrm{~h}$ and (b) $3000 \mathrm{~h}$ showing $\mathrm{Ll}_{2}$ precipitate growth. 


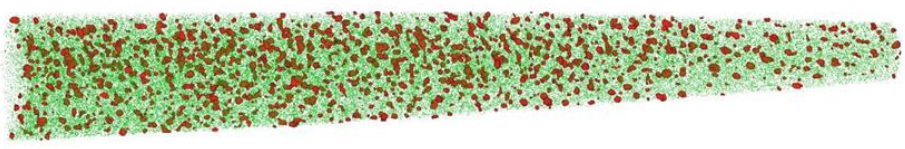

$100 \mathrm{~nm}$

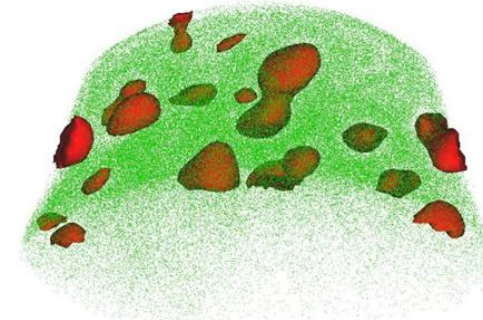

$20 \mathrm{~nm}$

Figure 8. An APT reconstruction of the AFA26 specimen with the $\mathrm{L}_{2}-\gamma$ ' particles bound by red isoconcentration surfaces: (a) as-processed alloy with a 45 at. \% Ni isoconcentration surface and (b) aged at $750^{\circ} \mathrm{C}$ for $2 \mathrm{~h}$ with a 55 at. $\% \mathrm{Ni}$ isoconcentration surface. The green points indicate the $\mathrm{Fe}$ in the f.c.c. matrix. 


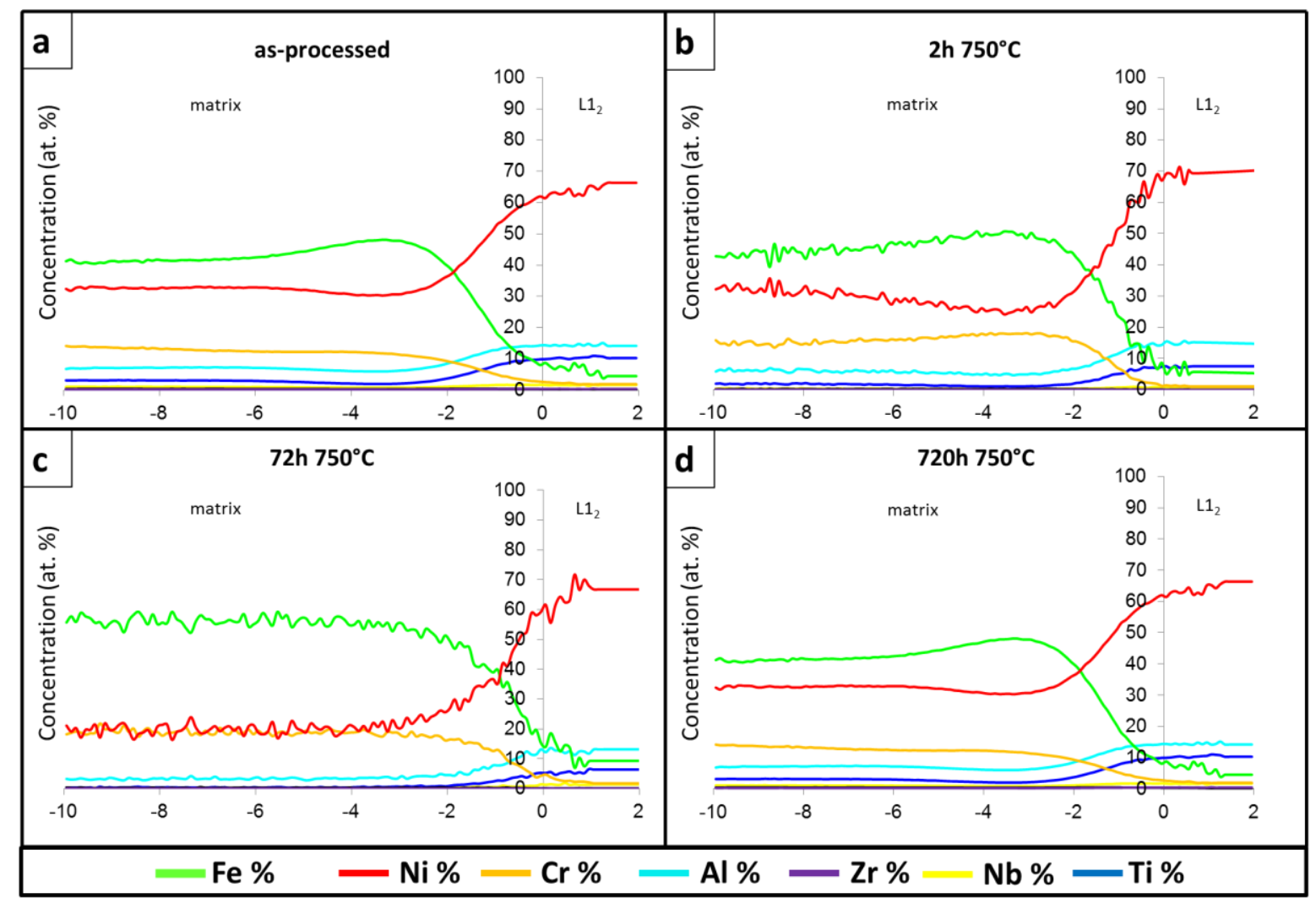

Figure 9. Proximity histogram across $\gamma$-f.c.c. matrix and a $\gamma^{\prime}-\mathrm{L} 1_{2}$ phase particle interfaces in AFA26: (a) as-processed; and aged at $750^{\circ} \mathrm{C}$ for (b) $2 \mathrm{~h}$, (c) $72 \mathrm{~h}$ and (d) $720 \mathrm{~h}$. The iron and nickel-rich f.c.c. matrix is on the left hand side and the $\gamma^{\prime}-\mathrm{L} 1_{2}$ phase particle is on the right hand side. 


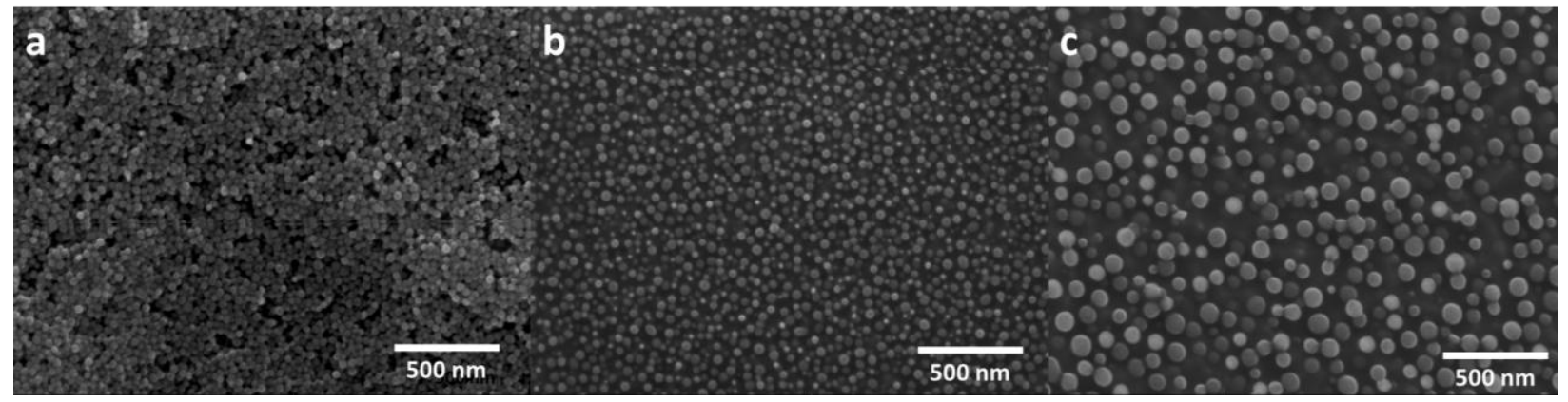

Figure 10. SE images of the $\mathrm{L} 1_{2}$ particles in AFA26 specimens aged at $800^{\circ} \mathrm{C}$ for: (a) $2.4 \mathrm{~h}$; (b) $24 \mathrm{~h}$ and (c) $240 \mathrm{~h}$. 


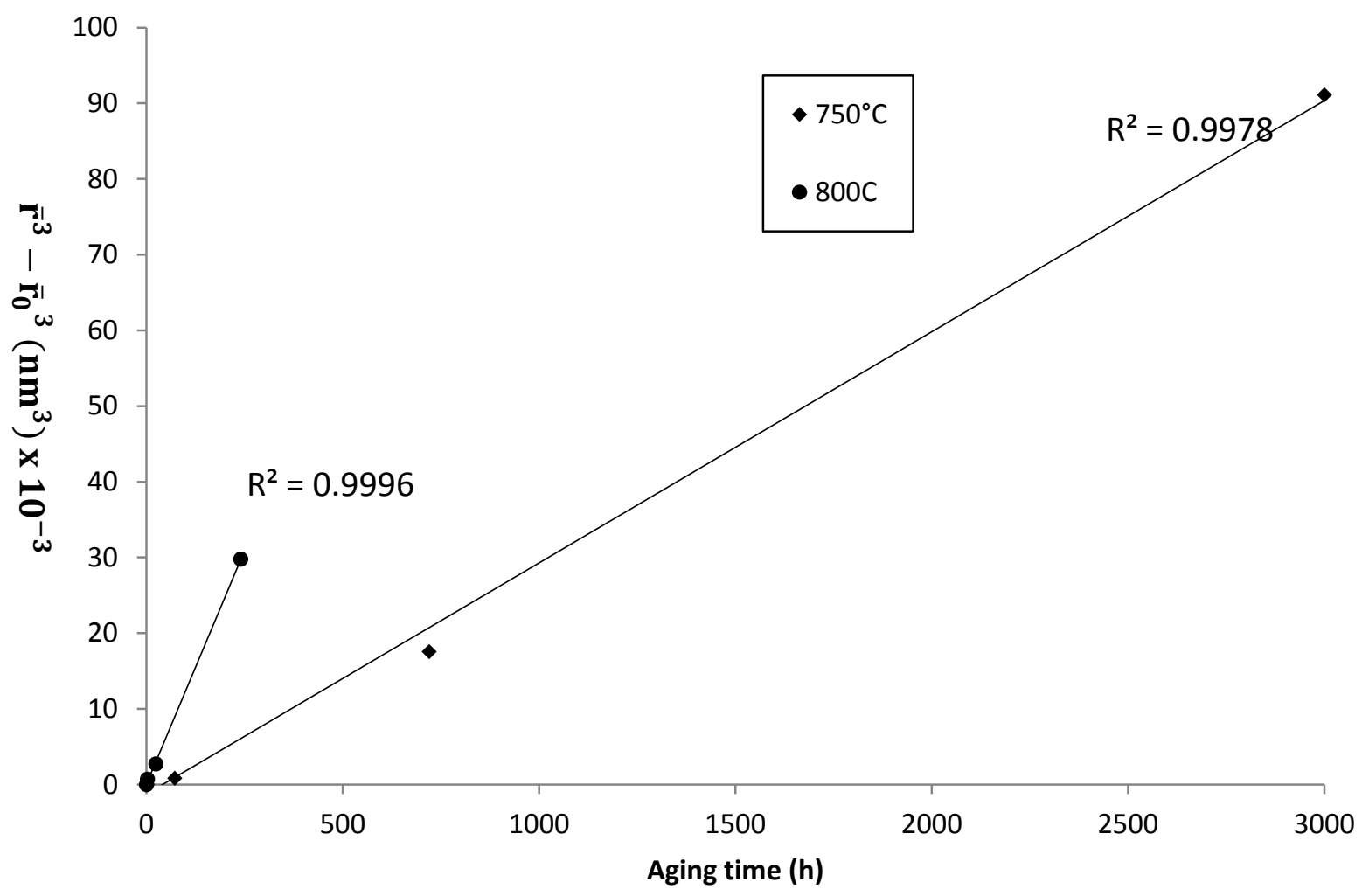

Figure 11. Plot of $\overline{\mathrm{r}}^{3}-\overline{\mathrm{r}}_{0}{ }^{3}$ versus aging for $\gamma^{\prime}$ particles in AFA26 aged at 750 and $800^{\circ} \mathrm{C}$. 


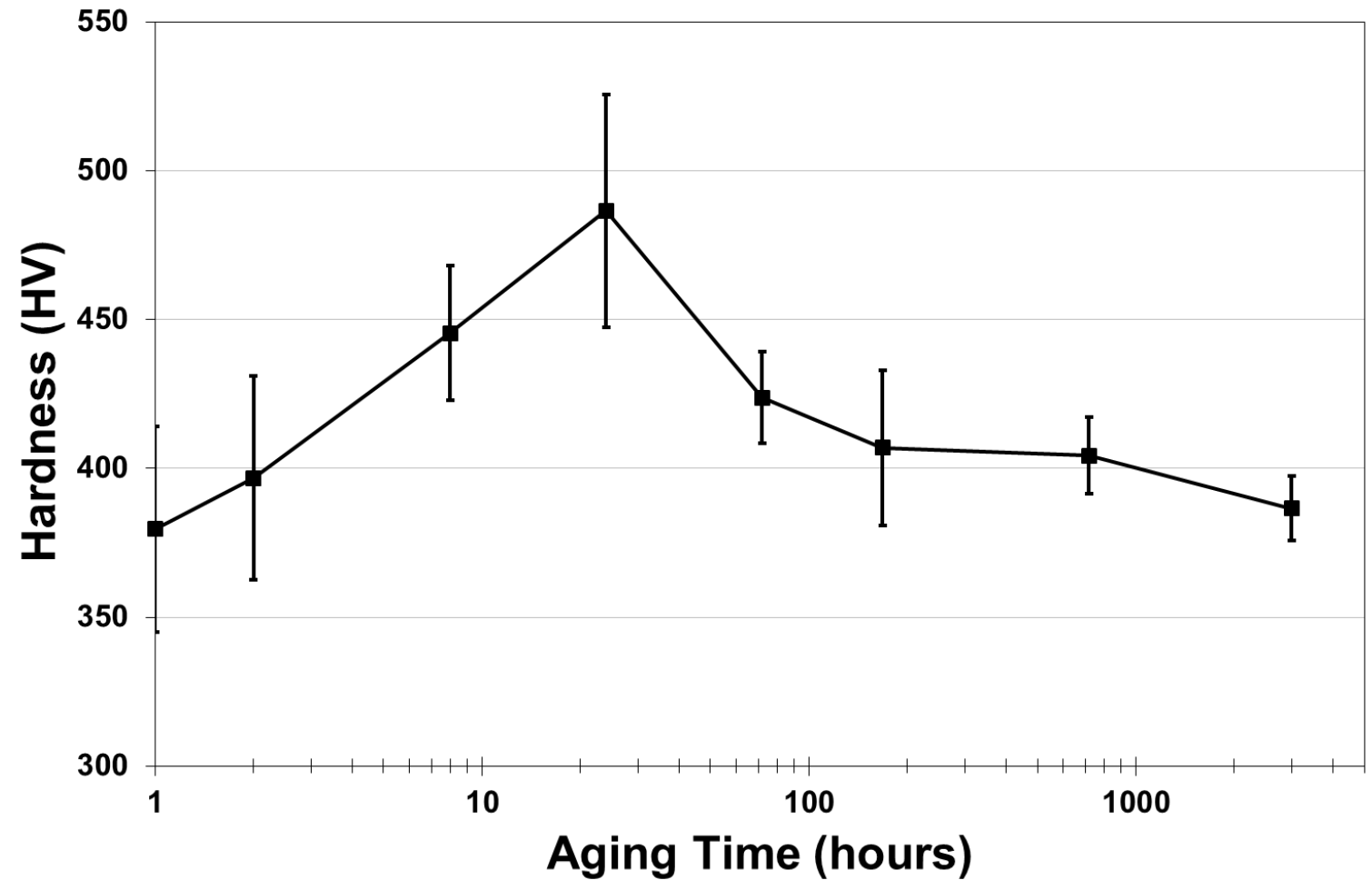

Figure 12. Hardness values for AFA26 aged at $750^{\circ} \mathrm{C}$ with error bars indicating measurement standard deviation from 10 indents at each aging time. 
Table 1. AFA26 alloy composition (nominal and analyzed)

\begin{tabular}{|c|c|c|c|c|c|c|c|c|c|c|c|c|c|c|c|}
\hline $\begin{array}{l}\text { AFA26 } \\
\text { (at. \%) }\end{array}$ & $\mathrm{Fe}$ & $\mathrm{Cr}$ & $\mathrm{Ni}$ & Al & $\mathrm{Si}$ & $\mathrm{Nb}$ & $\mathrm{Ti}$ & W & $\mathrm{Zr}$ & C & B & $\mathbf{P}$ & $S$ & 0 & $\mathbf{N}$ \\
\hline Nominal & 44.7 & 14.8 & 29.9 & 6.1 & 0.3 & 1.8 & 2.3 & - & 0.2 & - & - & - & - & - & - \\
\hline Analyzed & 44.56 & 14.79 & 30.39 & 5.97 & 0.25 & 1.74 & 2.26 & 0.003 & 0.006 & 0.009 & $<0.002$ & $<0.004$ & $<0.000$ & $2<0.004$ & $<0.0016$ \\
\hline
\end{tabular}

